BANCA D'ITALIA

E U R O S I S T E M A

Temi di discussione

(Working Papers)

Disinflationary shoeks and inflation target uncertainty

by Stefano Neriand Tiziano Ropele 

BANCA D'ITALIA

E UROS I S T E MA

\section{Temi di discussione}

(Working Papers)

Disinflationary shocks and inflation target uncertainty

by Stefano Neri and Tiziano Ropele

Number 1230 - July 2019 
The papers published in the Temi di discussione series describe preliminary results and are made available to the public to encourage discussion and elicit comments.

The views expressed in the articles are those of the authors and do not involve the responsibility of the Bank.

Editorial Board: Federico Cingano, Marianna Riggi, Monica Andini, Audinga Baltrunaite, Emanuele Ciani, Nicola Curci, Davide Delle Monache, Sara Formai, Francesco Franceschi, Juho Taneli Makinen, Luca Metelli, Valentina Michelangeli, Mario Pietrunti, Massimiliano Stacchini.

Editorial Assistants: Alessandra Giammarco, Roberto Marano.

ISSN 1594-7939 (print)

ISSN 2281-3950 (online)

Printed by the Printing and Publishing Division of the Bank of Italy 


\title{
DISINFLATIONARY SHOCKS AND INFLATION TARGET UNCERTAINTY
}

\author{
by Stefano Neri ${ }^{*}$ and Tiziano Ropele
}

\begin{abstract}
In New Keynesian models favourable cost-push shocks lower inflation and increase output. Yet, when the central bank's inflation target is not perfectly observed these shocks turn contractionary as agents erroneously perceive a temporary reduction in the target. This effect is amplified when monetary policy is constrained by the effective lower bound on the policy rate.
\end{abstract}

JEL Classification: E31, E52, E58.

Keywords: inflation target, imperfect information, monetary policy.

\section{Contents}

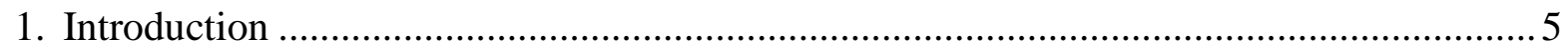

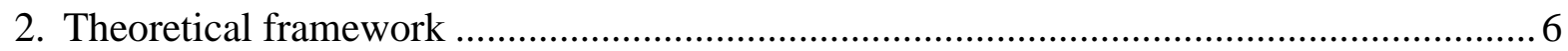

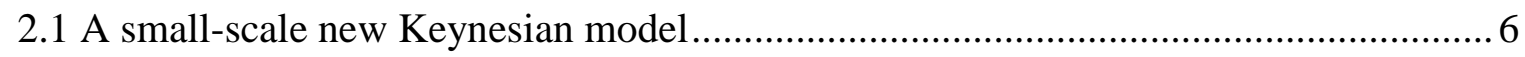

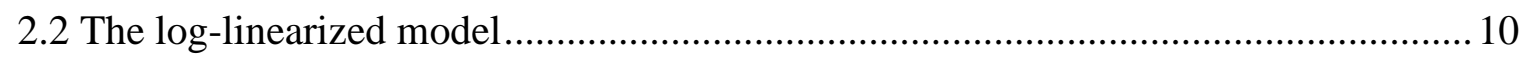

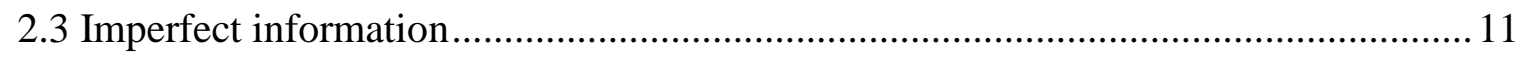

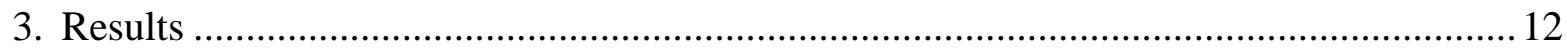

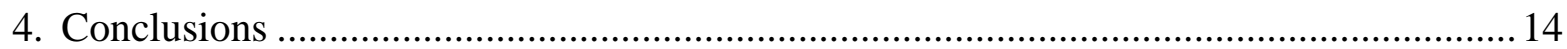

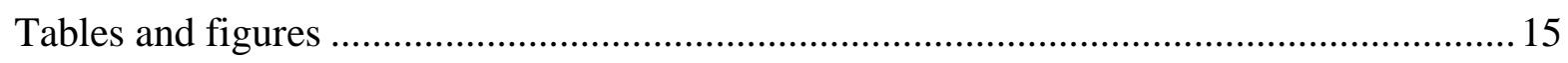

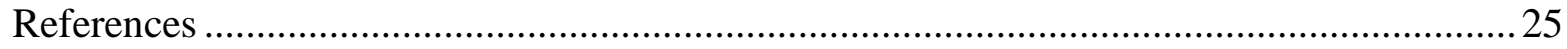

\footnotetext{
* Banca d'Italia, Economic Outlook and Monetary Policy Directorate.

${ }^{* *}$ Banca d'Italia, Regional Economic Unit in Milan.
} 



\section{Introduction ${ }^{1}$}

Nowadays many central banks rely on a formalized inflation-targeting framework based on the belief and the theoretical predictions that an explicit and clearly communicated target helps anchoring long-term inflation expectations and making monetary policy more effective (Bernanke and Mishkin, 1997). ${ }^{2}$ However, not all central banks have or have had a precise inflation target. The Federal Open Market Committee of the Federal Reserve clarified that its long-run inflation target was 2 per cent only in January 2012. The European Central Bank has never clarified the meaning of "below, but close to 2 per cent" in its definition of price stability. ${ }^{3}$ Several studies have shown that in countries that adopted inflation targeting, inflation and inflation expectations react less and in less persistent manner to oil or food price shocks than in non-inflation targeting countries (Mishkin and Schmidt-Hebbel, 2007; Davis, 2014; Gelos and Ustyugova, 2017).

In this paper we ask the following question: What is the impact of a favourable cost-push shock on the economy when the inflation target is imperfectly observed (or not communicated precisely by the central bank)? We answer this question using a small-scale New Keynesian model featuring symmetric imperfect information (II, henceforth) about the state of the economy, including the inflation target. We show that under II, the transmission of a favourable cost-push shock changes substantially compared with the case of perfect information (PI, henceforth). Rather than moving output and inflation in opposite directions (i.e. inflation down and output up), under II both variables fall. In this case, agents misperceive the occurrence of shocks and erroneously believe that also negative shocks to preference and to the inflation target have materialized, which in turn give rise to a decline in inflation and output. Output and inflation fall even more if the central bank cannot reduce its policy rate due to the effective lower bound (ELB). More generally, and in line with the existing literature, under II on the state of the economy agents and the central bank respond less aggressively to the shocks.

\footnotetext{
1 The opinions expressed in this paper are those of the authors and do not reflect those of Banca d'Italia. The authors would like to thank an anonymous referee, Guido Ascari and participants at the workshop on "Low inflation and its implications for monetary policy", held at Banca d'Italia on 23 March 2015 and at the 11 thDynare conference held at the National Bank of Belgium on 28-29 September 2015. A shorter version can be found in Economics Letters (Vol. 181, 2019).

2 Capistrán and Ramos-Francia (2007) show that in inflation targeting regimes inflation, forecasts by professional forecasters are less dispersed.

3 Several central banks with an inflation targeting framework have a target range (e.g. the Reserve Bank of New Zealand) rather than a point target for inflation.
} 
The literature has extensively studied monetary policy under PI. Few studies, however, have examined the macroeconomic implications of imperfect information about inflation target. Erceg and Levine (2003) set up a New Keynesian model in which private agents have limited information about the central bank's objectives and must disentangle persistent shifts in the inflation target from transitory monetary policy shocks. They show that disinflationary monetary policies generate larger output costs in this setting than under PI. Using a similar model, Melecky, Palenzuela and Söderström (2009) show that the announcement of an inflation target yields substantial macroeconomic gains when the private sector overestimates the volatility of the target. This paper contributes to this literature along two dimensions. First, we document that imperfect observability of the inflation target changes the transmission of cost-push shocks. Second, we consider the interaction between this imperfect observability and the ELB.

\section{Theoretical framework}

\subsection{A small-scale new Keynesian model}

In this section we describe the key features of a small-scale new Keynesian DSGE model that we use for the purposes of our analysis. The economy is populated by a representative household that consumes and supplies labour, finished-goods-producing firms, intermediategoods-producing firms and a central bank in charge of monetary policy. For many aspects the model is similar to Clarida, Galí and Gertler (1999), Galí (2003) and Woodford (2003). The two main differences pertain to a generalization of the quadratic adjustment cost mechanism à la Rotemberg (1982) and to the presence of a time-varying inflation target. Furthermore, the model is solved under two alternative information settings regarding the knowledge of the state of the economy: either under PI or symmetric II, as in Svensson and Woodford (2003).

\section{The representative household}

The representative household lives forever and her expected lifetime utility is given by:

$$
E_{0} \sum_{t=0}^{\infty} d_{t} \beta^{t}\left\{\log \left(C_{t}-\gamma \bar{C}_{t-1}\right)-H_{t}\right\}
$$

where $E_{0}$ is the rational expectation operator conditional on time $t=0$ information and $\beta \in(0,1)$ is the subjective rate of time preference. The instantaneous utility function is increasing in the consumption of a final good $\left(C_{t}\right)$ relative to a level of external habit defined in terms of lagged aggregate consumption $\left(\bar{C}_{t-1}\right)$ and parameterized by $\gamma$, and decreasing in 
labour $\left(H_{t}\right)$. The variable $d_{t}$ represents a preference shock that evolves according to $\log \left(d_{t}\right)=\rho_{d} \log \left(d_{t-1}\right)+\varepsilon_{d, t}$, with $\rho_{d} \in[0,1]$ and $\varepsilon_{d, t} \sim N\left(0, \sigma_{d}^{2}\right)$.

At a given period $t$, the representative household faces the following budget constraint:

$$
P_{t} C_{t}+B_{t} \leq P_{t} w_{t} H_{t}+\left(1+i_{t-1}\right) B_{t-1}+F_{t}
$$

where $P_{t}$ is the price of the final good, $B_{t}$ represents holding of bonds offering a one-period nominal return $i_{t}, w_{t}$ is the real wage, and $F_{t}$ are firms' profits that are returned to households. Solving the representative household's utility maximization yields the following first order conditions:

$$
\begin{gathered}
u_{c, t}=\beta\left(1+i_{t}\right) E_{t}\left(\frac{u_{c, t+1}}{P_{t+1} / P_{t}}\right) \\
d_{t}=u_{c, t} w_{t},
\end{gathered}
$$

where $u_{c, t} \equiv\left(C_{t}-\gamma \bar{C}_{t-1}\right)^{-1} d_{t}$ is the marginal utility of consumption. Equations (3) and (4) have the usual economic interpretation.

\section{Finished-goods-producing firms}

In each period a final good $Y_{t}$ is produced by perfectly competitive firms using a continuum of intermediate inputs $Y_{i, t}$ indexed by $i \in(0,1)$ and a CES production function:

$$
Y_{t}=\left[\int_{0}^{1} Y_{i, t}^{\left(\theta_{t}-1\right) / \theta_{t}} d i\right]^{\theta_{t} /\left(\theta_{t}-1\right)}
$$

where $\theta_{t}$ follows the stationary autoregressive process

$$
\log \left(\theta_{t}\right)=\left(1-\rho_{\theta}\right) \log (\theta)+\rho_{\theta} \log \left(\theta_{t}\right)+\varepsilon_{\theta, t}
$$

with $\rho_{\theta} \in[0,1]$ and $\varepsilon_{\theta, t} \sim N\left(0, \sigma_{\theta}^{2}\right)$. Taking prices as given the final good producer chooses intermediate good quantities $Y_{i, t}$ to maximise profits, resulting in the usual demand schedule:

$$
Y_{i, t}=\left(\frac{P_{i, t}}{P_{t}}\right)^{-\theta_{t}} Y_{t}
$$

The zero-profit condition of final good producers leads the aggregate price index:

$$
P_{t}=\left[\int_{0}^{1} P_{i, t}^{1-\theta_{t}} d i\right]^{1 /\left(1-\theta_{t}\right)} .
$$




\section{Intermediate-goods-producing firms}

Intermediate inputs $Y_{i, t}$ are produced by a continuum of firms indexed by $i \in(0,1)$ with the technology:

$$
Y_{i, t}=H_{i, t}
$$

Prices are sticky, with intermediate goods producers in monopolistic competition setting prices according to a generalized quadratic adjustment cost mechanism à la Rotemberg (1982). As in Ireland (2007), we assume that the quadratic adjustment cost, measured in terms of the final good, is given by the following specification:

$$
\Gamma_{i, t}=\frac{\phi}{2}\left\{\frac{P_{i, t}}{\left[\Pi_{t-1}^{\alpha}\left(\Pi_{t}^{*}\right)^{1-\alpha}\right] P_{i, t-1}}-1\right\}^{2} Y_{t}
$$

where the parameter $\phi \in[0, \infty)$ measures the magnitude of the adjustment cost, $\Pi_{t} \equiv P_{t} / P_{t-1}$ so that $\Pi_{t-1}$ denotes the gross inflation rate between $t-2$ and $t-1, \Pi_{t}^{*}$ denotes the central bank's time-varying inflation target for period $t$, and the parameter $\alpha \in[0,1]$ determines to what extent intermediate firms' price setting is backward- instead of forward-looking. When $\alpha=0$, so that firms find it costless to adjust their prices in line with the central bank's inflation target, the Phillips curve becomes purely forward-looking. When $\alpha=1$, so that firms find it costless to adjust their prices in line with the previous period's inflation rate, the backwardlooking term in the Phillips curve becomes as important as the forward-looking term. Notice that according to (10) prices are fully indexed and thus there are not distortionary effects stemming from positive levels of steady-state inflation. ${ }^{4}$

The problem for the intermediate firm $i$ is then:

$$
\begin{gathered}
\max _{\left\{P_{i, t}\right\}_{t=0}^{\infty}} E_{t} \sum_{j=0}^{\infty} \frac{\beta^{j} u_{c, t+j}}{u_{c, t}}\left\{\frac{P_{i, t+j}}{P_{t+j}} Y_{i, t+j}-w_{t+j} Y_{i, t+j}-\Gamma_{i, t+j}\right\} \\
\text { subject to: } Y_{i, t+j}=\left[\frac{P_{i, t+j}}{P_{t+j}}\right]^{-\theta_{t}} Y_{t+j} .
\end{gathered}
$$

Intermediate firms can change their price in each period, subject to the payment of the adjustment cost. All firms face the same problem. Hence they will choose the same price and 
output: $P_{i, t}=P_{t}$ and $Y_{i, t}=Y_{t}$ for every $i$. Exploiting the symmetry of the equilibrium, the firstorder condition for the above maximization yields:

$$
\begin{aligned}
\theta_{t}-1 & =\theta_{t} w_{t}-\phi\left[\frac{\Pi_{t}}{\Pi_{t-1}^{\alpha}\left(\Pi_{t}^{*}\right)^{1-\alpha}}-1\right] \frac{\Pi_{t}}{\Pi_{t-1}^{\alpha}\left(\Pi_{t}^{*}\right)^{1-\alpha}}+ \\
& +\beta \frac{u_{c, t+1}}{u_{c, t}} \phi\left[\frac{\Pi_{t+1}}{\Pi_{t}^{\alpha}\left(\Pi_{t+1}^{*}\right)^{1-\alpha}}-1\right] \frac{\Pi_{t+1}}{\Pi_{t}^{\alpha}\left(\Pi_{t+1}^{*}\right)^{1-\alpha}} \frac{Y_{t+1}}{Y_{t}}
\end{aligned}
$$

\section{Central bank}

The central bank sets monetary policy according to the generalized Taylor (1993) rule:

$$
1+\mathrm{i}_{t}=(1+\overline{\mathrm{l}})\left(\frac{1+\mathrm{i}_{t-1}}{1+\overline{\mathrm{l}}}\right)^{\phi_{i}}\left(\frac{\Pi_{t}}{\Pi_{t}^{*}}\right)^{\left(1-\phi_{i}\right) \phi_{\pi}}\left(\frac{Y_{t}}{\bar{Y}}\right)^{\left(1-\phi_{i}\right) \phi_{y}}
$$

where $\phi_{i} \in[0,1], \phi_{\pi} \in[0, \infty)$ and $\phi_{y} \in[0, \infty)$. According to (13) the central bank increases the short-term nominal rate $i_{t}$ whenever inflation rises above its target $\Pi_{t}^{*}$ and/or when output is above its steady-state level $\bar{Y}$. Provided that $\phi_{i} \in(0,1]$ the policy rule exhibits an inertial behaviour. As in Ireland (2007), a novel feature of the generalized Taylor rule (13) is the fact that the central bank's inflation target $\Pi_{t}^{*}$ is time-varying. We assume that the target evolves according to the following exogenous AR(1) process:

$$
\log \left(\Pi_{t}^{*}\right)=\left(1-\rho_{\Pi}\right) \log \left(\Pi^{*}\right)+\rho_{\Pi} \log \left(\Pi_{t-1}^{*}\right)+\varepsilon_{\Pi, t}
$$

where $\Pi^{*}$ represents the long-run inflation target, $\rho_{\Pi} \in(0,1)$ and $\varepsilon_{\Pi, t} \sim N\left(0, \sigma_{\pi^{*}}^{2}\right)$. Unlike Ireland (2007) where the central bank is allowed to systematically adjust its inflation target in response to the structural shocks hitting the economy, here we simply assume that inflation target varies exogenously in response to realizations of the disturbance $\varepsilon_{\Pi, t}$. As discussed more extensively in Section 3, we assume a very small value for $\sigma_{\pi^{*}}^{2}$ and a value close to one for $\rho_{\Pi}$ so that the inflation target exhibits highly persistent dynamics.

\section{Aggregate resource constraint}

It is important to note that the adjustment cost creates an inefficiency wedge between aggregate output and aggregate consumption, as the resource constraint shows:

$$
\mathrm{Y}_{t}=\mathrm{C}_{t} /\left\{1-\frac{\phi}{2}\left[\frac{\Pi_{t}}{\Pi_{t-1}^{\alpha}\left(\Pi_{t}^{*}\right)^{1-\alpha}}-1\right]^{2}\right\}
$$


Note that absent any price indexation, i.e. $\Pi_{t-1}^{\alpha}\left(\Pi_{t}^{*}\right)^{1-\alpha} \equiv 1$, the inefficiency wedge would increase with inflation: the higher inflation, the higher the size of the price change and hence the higher the adjustment costs that firms have to pay. However, with full price indexation this inefficiency wedge washes out both in steady state and in the (log-)linear approximation of the model.

\subsection{The log-linearized model}

We now present the log-linearized version of the model approximated around the deterministic steady state. ${ }^{5}$ Throughout, for any variable $x_{t}$ we let $\hat{x}_{t}=\log (X) / \log (\bar{X})$.

The linearized model is given by the following equations:

$$
\begin{gathered}
\hat{y}_{t}=\left(\frac{\gamma}{1+\gamma}\right) \hat{y}_{t-1}+\left(\frac{1}{1+\gamma}\right) y_{t+1 \mid t}-\left(\frac{1-\gamma}{1+\gamma}\right)\left(\hat{\imath}_{t}-\hat{\pi}_{t+1 \mid t}\right)+\left(\frac{1-\gamma}{1+\gamma}\right)\left(1-\rho_{d}\right) \hat{d}_{t} \\
\hat{\pi}_{t}=\left(\frac{\alpha}{1+\alpha \beta}\right) \hat{\pi}_{t-1}+\left(\frac{\beta}{1+\alpha \beta}\right) \hat{\pi}_{t+1 \mid t}+\left[\frac{1}{\phi(1+\alpha \beta)}\right]\left(\frac{\theta-1}{1-\gamma}\right)\left(\hat{y}_{t}-\gamma \hat{y}_{t-1}\right)+ \\
+\left[\frac{(1-\alpha)\left(1-\beta \rho_{\Pi}\right)}{1+\alpha \beta}\right] \hat{\pi}_{t}^{*}+\hat{s}_{t} \\
\hat{\imath}_{t}=\phi_{i} \hat{\imath}_{t-1}+\left(1-\phi_{i}\right)\left[\phi_{\pi}\left(\hat{\pi}_{t}-\hat{\pi}_{t}^{*}\right)+\phi_{y} \hat{y}_{t}\right] \\
\hat{d}_{t}=\rho_{d} \hat{d}_{t-1}+\varepsilon_{d, t}, \\
\hat{s}_{t}=\rho_{s} \hat{s}_{t-1}+\varepsilon_{s, t}, \\
\hat{\pi}_{t}^{*}=\rho_{\pi} \hat{\pi}_{t-1}^{*}+\varepsilon_{\pi, t},
\end{gathered}
$$

where $\hat{s}_{t} \equiv \frac{1}{\phi(1+\alpha \beta)} \theta_{t}$.

Equation (16) is a standard hybrid IS curve in which current output depends positively on the lagged and the next period expected output and is inversely related to the ex-ante real interest rate. As the parameter $\gamma$ increases the degree of persistence of output rises. The preference shock $d_{t}$ acts as a demand shifter.

Equation (17) is a hybrid new-Keynesian Phillips curve (NKPC) in which current inflation is a function of past and expected inflation and also of the current and lagged output. Two 
remarks are in order. First, the time-varying inflation target enters the hybrid NKCP with a positive coefficient. This is the result of the indexation scheme according to which past prices are automatically increased by a factor that depends on $\Pi_{t}^{*}$. Hence a decline in the inflation target lowers inflation. Second, the hybrid NKPC is shifted by the cost-push shock $\hat{s}_{t}$, which arises from the time-varying elasticity of substitution $\theta_{t}$.

Equation (18) is instead a generalized Taylor rule for the nominal short-term rate that exhibits inertia and is defined in terms of an inflation gap (expressed in deviation from the time-varying inflation target) and an output gap (expressed in deviation from the steady-state of output). Equations (19)-(21) describe the law of motion of the three exogenous processes, namely the preference shock, the cost-push shock and the time-varying inflation target shock. As anticipated, each of them follows an AR(1) process.

\subsection{Imperfect information}

As in Svensson and Woodford (2003), agents and the central bank do not perfectly observe the state of the economy, given by $X_{t} \equiv\left\{\hat{y}_{t-1}, \hat{\pi}_{t-1}, \hat{d}_{t}, \hat{s}_{t}, \hat{\pi}_{t}^{*}\right\}{ }^{6}$ The central bank responds, in accordance with equation (18), to the estimate of the current output gap $\left(\hat{y}_{t \mid t}\right)$ and to the gap between inflation $\left(\hat{\pi}_{t \mid t}\right)$ and the target $\left(\hat{\pi}_{t \mid t}^{*}\right)$. The fact that the central bank does not know the inflation target might seem odd. However, this assumption is meant to capture the very realistic situation in which policy decisions taken by a committee - as is the case for monetary policy - are an outcome of members' policy choices and preferences and that these preferences may differ amongst the members (Blinder, 2007). According to (18), we let the inflation target to temporarily deviate from its steady-state (long-run) level.

The estimate of the state of the economy $\left(X_{t \mid t}\right)$ and thus of current output and inflation (given by $x_{t \mid t}=\mathbf{G}^{*} X_{t \mid t}$, where $x_{t \mid t} \equiv\left\{\hat{y}_{t \mid t}, \hat{\pi}_{t \mid t}\right\}$ and $\mathbf{G}^{*}$ is computed independently from the problem of estimating $X_{t \mid t}$, i.e. the "separation principle" holds) are described by:

$$
\begin{gathered}
X_{t \mid t}=X_{t \mid t-1}+\mathbf{K}\left(Z_{t}-Z_{t \mid t-1}\right) \\
Z_{t}=\mathbf{L} X_{t}+\mathbf{M} X_{t \mid t}+v_{t}
\end{gathered}
$$

where $Z_{t}$ includes the observable but noisy indicators:

\footnotetext{
${ }^{6}$ Svensson and Woodford (2004) consider a framework in which the private sector and the central bank have different information sets. In this case, the separation principle between optimization and filtering does not hold.
} 


$$
Z_{t} \equiv\left[\begin{array}{c}
\hat{y}_{t}^{o b s} \\
\hat{\pi}_{t}^{o b s} \\
\hat{\pi}_{t}^{*, o b s}
\end{array}\right]=\left[\begin{array}{c}
\hat{y}_{t} \\
\hat{\pi}_{t} \\
\hat{\pi}_{t}^{*}
\end{array}\right]+\left[\begin{array}{c}
v_{y, t} \\
v_{\pi, t} \\
v_{\pi^{*}, t}
\end{array}\right]
$$

where $v^{\prime}$ 's are measurement errors, which are normally distributed with zero mean and standard deviations $\sigma_{v, y}, \sigma_{v, \pi}$ and $\sigma_{v, \pi^{*}}$, respectively. The matrix $\mathbf{K}$ in (22) is the Kalman gain that weighs the information content of the indicators in (24) to estimate the unobserved state variables $X_{t \mid t}$.

Table 1 reports the calibrated parameters. The discount factor $\beta$ is set at the conventional value of 0.99 (as the time unit is a quarter). The degree of indexation of prices, $\alpha$, is set to 0.5 . The degree of habit in consumption, $\gamma$, is set at 0.25 as in Ireland (2007). The parameter measuring the cost for adjusting prices, $\phi$, and the steady-state value of the elasticity of substitution among goods, $\theta$, are taken from Gerali, Neri, Sessa and Signoretti (2010). The degree of inertia in the monetary policy rule, $\phi_{i}$, is set at zero, while the other parameters of the rule are taken from Taylor (1993). ${ }^{7}$

Turning to the parameters governing the stochastic processes of the shocks, we borrow from Neri and Ropele (2011) the estimated AR(1) coefficients of the preference and cost-push shocks (0.77 and 0.56, respectively) and the estimated standard deviations of their innovations (0.064 and 0.059 percentage points, respectively). Regarding the inflation target, we set the AR(1) coefficient at 0.9 and the standard deviation of the innovation at 0.01 percentage points. These figures are based on the estimates of an AR(1) process fitted on the five-year ahead euro-area inflation expectations taken from the ECB's Survey of Professional Forecasters (SPF). The standard deviations of the measurement errors on inflation and output are at 0.03 and 0.8 percentage points, respectively, following Coenen, Levin and Wieland (2005) while the standard deviation of the measurement error on the inflation target is calibrated at 0.16 percentage points based the standard deviation of the aggregate distribution of the SPF inflation expectations constructed using the individual replies.

\section{Results}

In this Section we assess the implications of an imperfectly observed inflation target for the transmission of the shocks, with a special focus on a favourable cost-push shock. ${ }^{8}$

\footnotetext{
7 The results are robust to setting $\phi_{i}$ at values consistent with the empirical literature.

8 The model is solved using the Matlab toolkit developed in Gerali and Lippi (2003).
} 


\section{Favourable cost-push shocks}

Figure 1 shows the path of the actual cost-push shock to a unit innovation (upper-left panel) and the perceived shocks (other panels) for different levels of measurement precision on the target. As shown, agents underestimate the magnitude of the actual cost-push shock and erroneously perceive the materialization of negative innovations to the preference and inflation target shocks too. ${ }^{9}$ The hump-shaped responses of the perceived inflation target and preference shocks mirror the hump-shaped adjustments of output and inflation due to habit formation in consumption and the indexation of prices to past inflation.

The charts in the left column of Figure 2 show the responses of output, inflation and the policy rate to a favourable cost-push shock under PI. In this case, the shock lowers inflation and the central bank cuts the policy rate to stimulate output and bring inflation back to steady state. The charts in the middle column show the responses under II. Misperception of the shocks leads to different dynamics of output and inflation compared with PI. Both inflation and output fall as agents erroneously perceive the occurrence of negative shocks to preferences and to the inflation target, the latter being equivalent to a contractionary monetary policy shock. The peak decline in output is about 0.05 per cent, compared with an increase of 4 per cent under PI. Were inflation perfectly measured (i.e. $\sigma_{v, \pi}=0$ ), the drop in output would be even larger. ${ }^{10}$ The charts in the right column show the responses in a scenario in which the economy is at the ELB. ${ }^{11}$ All previous results strengthen since monetary policy fails to offset the perceived negative shocks to preferences and to the inflation target. Output falls substantially regardless of the degree of noise on the target.

\section{Preference and inflation target shocks}

Agents misperceive the occurrence of shocks also when a negative preference shock hits the economy lowering both inflation and output (Figure 3). Agents perceive that a negative shock to the inflation target and a negative cost-push shock have occurred. Compared with the PI case, the perception of a much smaller preference shock leads to a much lower decline in inflation and a somewhat smaller fall in output (Figure 4). The central bank lowers the policy rate by a smaller amount, given that inflation responds less to the milder, perceived negative

\footnotetext{
${ }^{9}$ Misperception occurs also when the economy is hit by preference or inflation target shocks.

10 The fall in output also occurs when the inflation target is the only indicator measured with error (i.e. if $\sigma_{v, y}=\sigma_{v, \pi}=0$ ).

11 We do not model how the ELB is reached. We assume that the economy is at the ELB and it is not expected to leave this state. In order to "neutralize" the endogenous response of the central bank to $\left(\hat{\pi}_{t \mid t}-\hat{\pi}_{t \mid t}^{*}\right)$ and $\hat{y}_{t \mid t}$ we let the policy rule be highly inertial, i.e. $\hat{l}_{t}=0.999 \hat{l}_{t-1}+(1-0.999)\left[\phi_{\pi}\left(\hat{\pi}_{t \mid t}-\hat{\pi}_{t \mid t}^{*}\right)+\phi_{y} \hat{y}_{t \mid t}\right]$. This ensures that the Taylor principle is not violated.
} 
preference shock. When monetary policy is at the ELB, output and inflation decline slightly more than away from the constraint.

Agents perceive the occurrence of a negative preference shock and a negative cost-push shock also when the economy is hit by a negative shock to the inflation target (Figure 5). When the target is imperfectly observed, output and inflation barely decline compared with the PI case, since agents perceive a much smaller shock to the target (Figure 6). When monetary policy is constrained by the ELB, the decline of output and inflation is very similar to the case in which the central banks can adjust the policy rate.

\section{Robustness checks}

The results concerning the transmission of cost-push shocks are robust to assuming a larger or a smaller degree of habit in consumption, $\gamma$. In the case of $\gamma=0.5$, which is twice larger the value used in the baseline simulations, the effects on output are somewhat stronger (Figure 7). The opposite occurs when the parameter is set to zero, although the results still hold from a qualitative point of view (Figure 8). In the case of no indexation of prices to past inflation $(\alpha=0)$, the effects of a favourable cost-push shock are larger than in the baseline case and the response of output displays a more hump-shaped pattern (Figure 9). In all the three cases, the larger is the noise on the inflation target, the larger is the impact of the costpush shock on output.

\section{Conclusions}

A small-scale New Keynesian model is used to study the effects of cost-push shocks when agents and the central bank do not perfectly observe the inflation target. Favourable costpush shocks have a negative impact on output. The effects are larger when monetary policy is at the effective lower bound. Reducing the noise on the perceived inflation target can mitigate the negative effects of cost-push shocks. The results are robust to varying the degree of habit in consumption and indexation of prices to past inflation.

Future research may test the implications of the results shown here using data on countries with different degrees of inflation target transparency and exploiting the effects of a common shock, such as to the supply of oil, for identification purpose. 


\section{Tables and figures}

Table 1. Calibrated parameters

\begin{tabular}{cccc}
\hline Parameter & Value & Description & Source \\
\hline$\beta$ & 0.99 & Discount factor & Authors' calibration \\
$\alpha$ & 0.50 & Prices indexation to past inflation & Authors' calibration \\
$\gamma$ & 0.25 & Habit formation in consumption & Ireland (2007) \\
$\phi$ & 30 & Price adjustment cost & Gerali et al. (2010) \\
$\theta$ & 6 & Elasticity of substitution among goods & Gerali et al. (2010) \\
$\phi_{\pi}$ & 1.5 & Response to inflation gap in monetary rule & Taylor (1993) \\
$\phi_{y}$ & 0.5 & Response to output gap in monetary rule & Taylor (1993) \\
$\rho_{d}$ & 0.77 & AR(1) coefficient: preference shock & Neri and Ropele (2011) \\
$\rho_{s}$ & 0.56 & AR(1) coefficient: cost-push shock & Neri and Ropele (2011) \\
$\rho_{\pi^{*}}$ & 0.90 & AR(1) coefficient: inflation target shock & Authors' calibration using SPF data \\
$\sigma_{d}$ & 0.00064 & Std. dev. innovation: preference shock & Neri and Ropele (2011) \\
$\sigma_{s}$ & 0.00059 & Std. dev. innovation: cost-push shock & Neri and Ropele (2011) \\
$\sigma_{\pi^{*}}$ & 0.0001 & Std. dev. innovation: inflation target shock & Authors' calibration using SPF data \\
$\sigma_{v, y}$ & 0.008 & Std. dev. meas. error: output & Coenen, Levin and Wieland (2005) \\
$\sigma_{v, \pi}$ & 0.0003 & Std. dev. meas. error: inflation & Coenen, Levin and Wieland (2005) \\
$\sigma_{v, \pi^{*}}$ & 0.0016 & Std. dev. meas. error: inflation target & Authors' calibration using SPF data \\
\hline
\end{tabular}

Notes: calibration of $\rho_{\pi^{*}}, \sigma_{\pi^{*}}$ and $\sigma_{v, \pi^{*}}$ is based on the five-year ahead inflation expectations from the ECB's Survey of Professional Forecasters. 
Figure 1. Impulse responses to a favorable cost-push shock
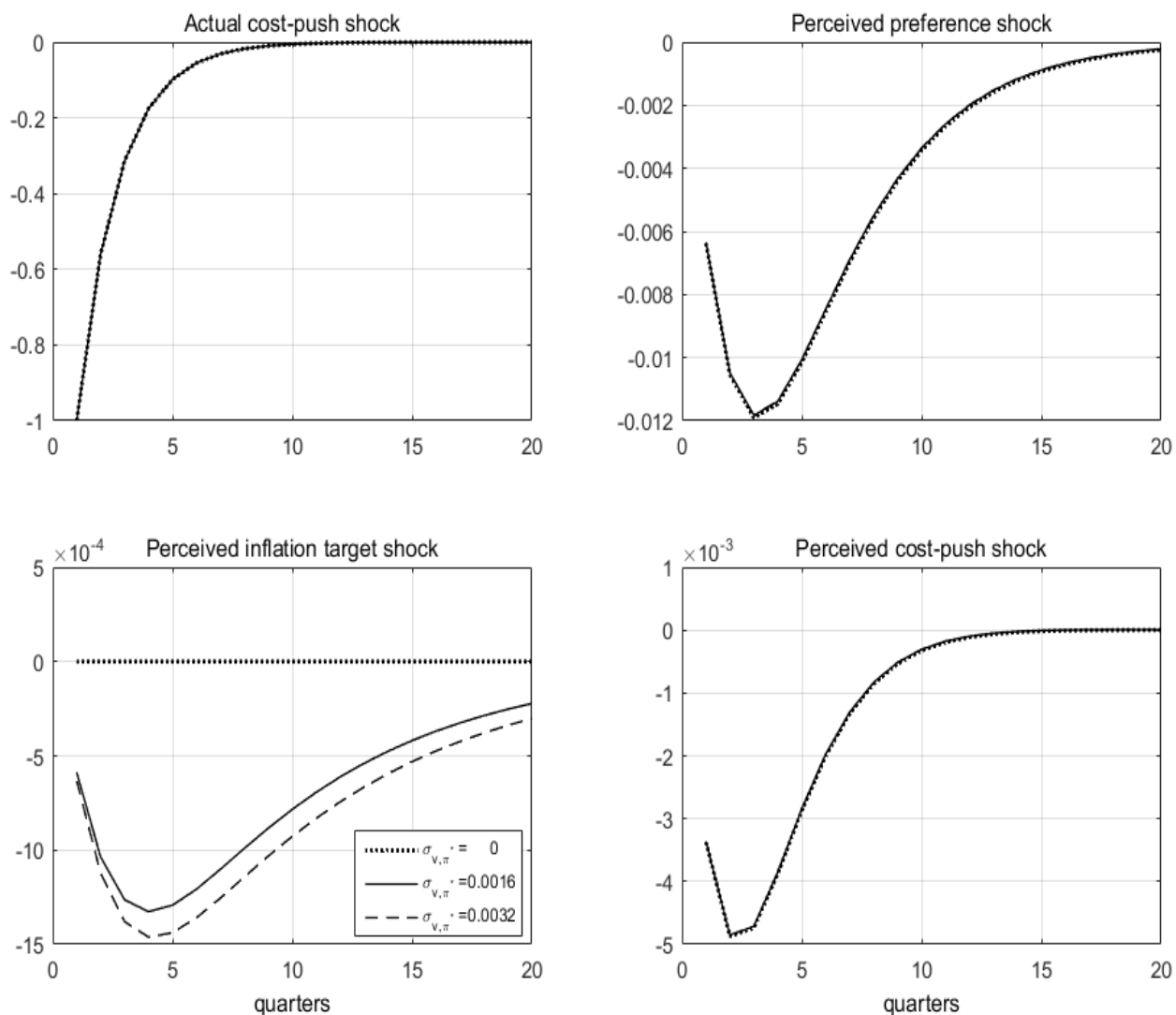

Notes: the figure shows the responses to a negative unit cost-push shock for different degrees of measurement precision of the inflation target. 
Figure 2. Impulse responses to a favorable cost-push shock (percentage deviations)
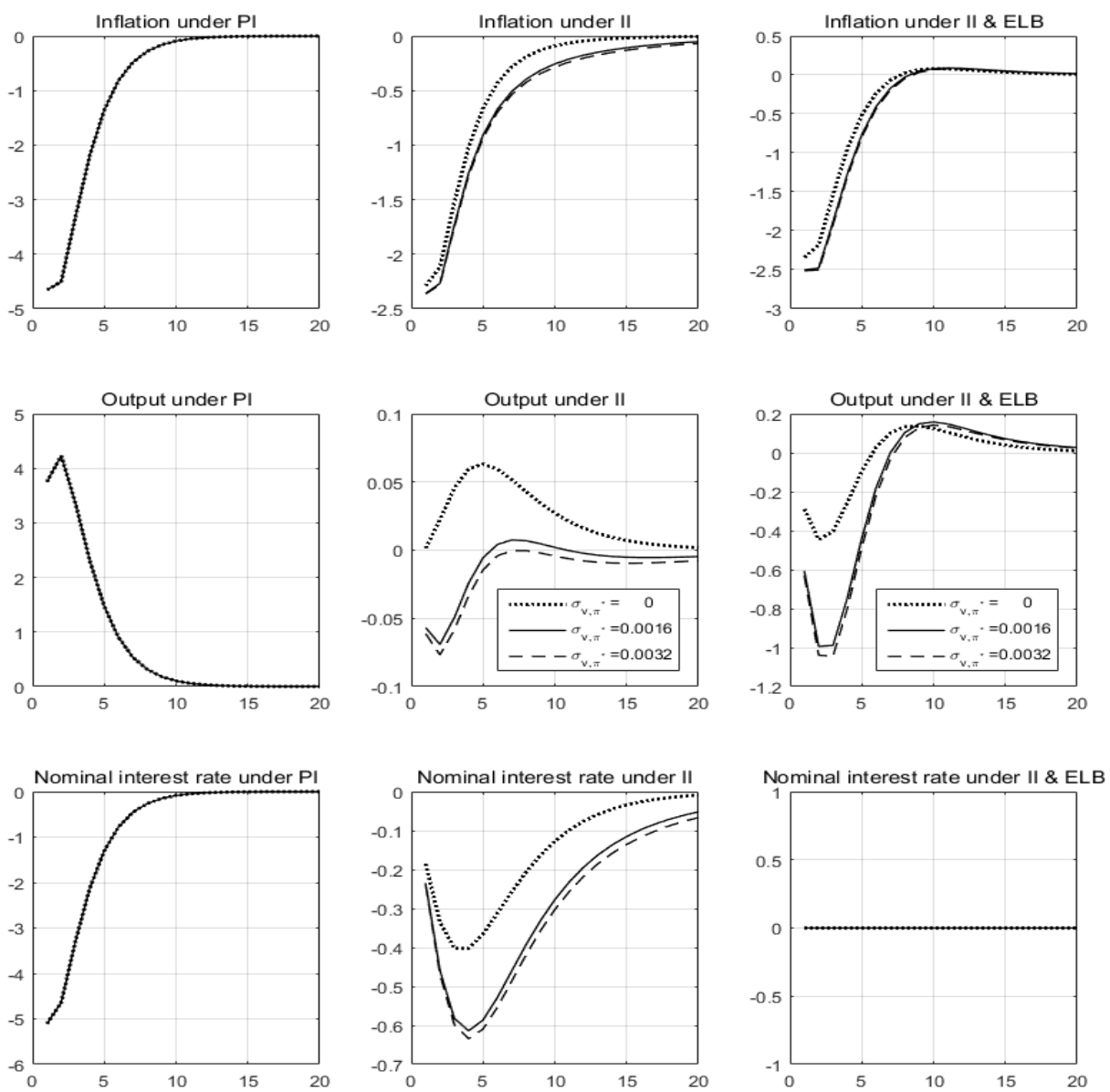

Notes: the charts in the left column show the responses under perfect information (PI). The charts in the middle column show the responses under imperfect information (II) and for different degrees of measurement precision of the inflation target. The charts in the right column show the responses under II and for different degrees of measurement precision of the inflation target when the interest rate is at its effective lower bound (ELB). 
Figure 3. Impulse responses to a negative preference shock
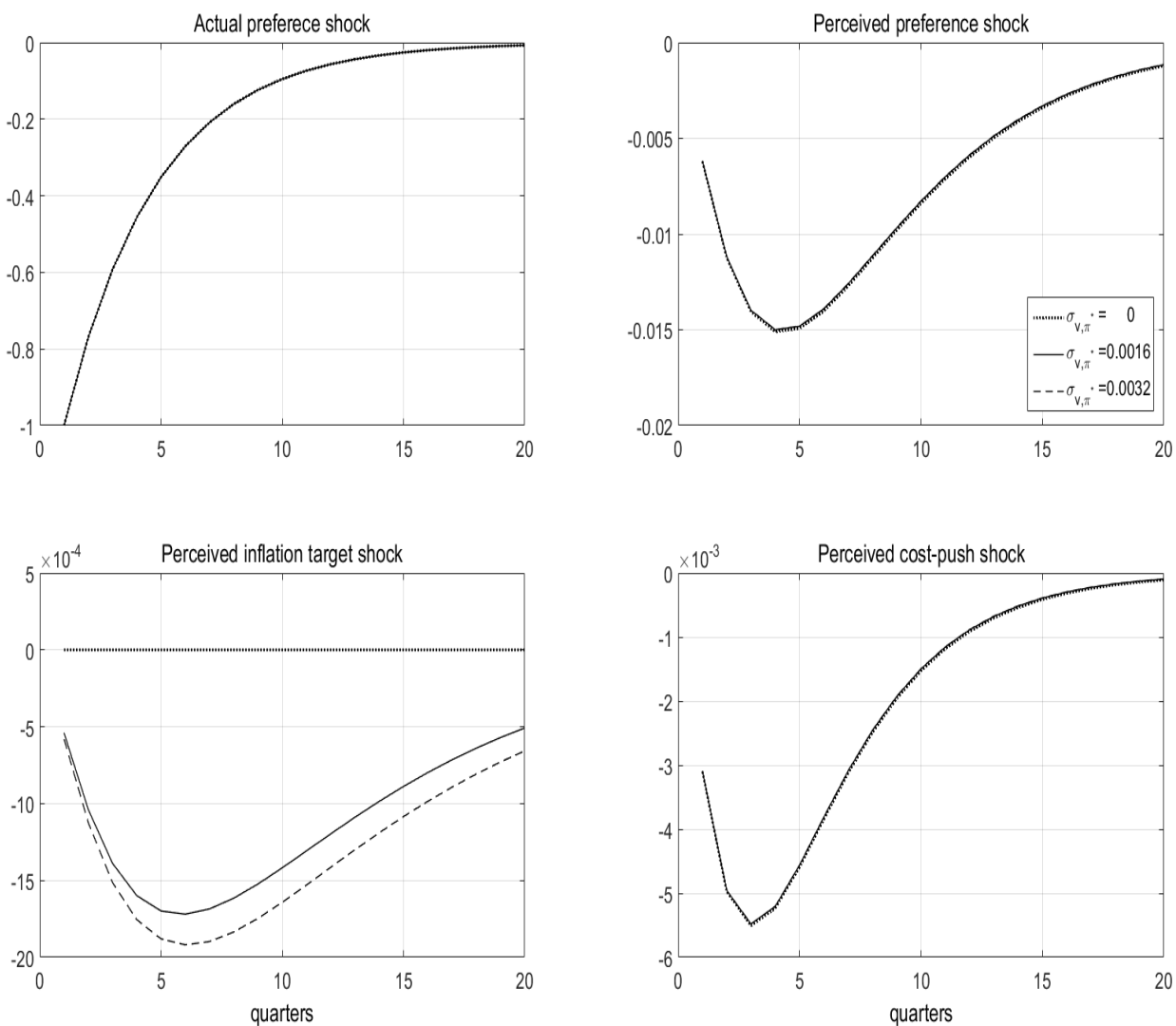

Notes: the figure shows the responses to a negative unit preference shock for different degrees of measurement precision of the inflation target. 
Figure 4. Impulse responses to a negative preference shock (percentage deviations)
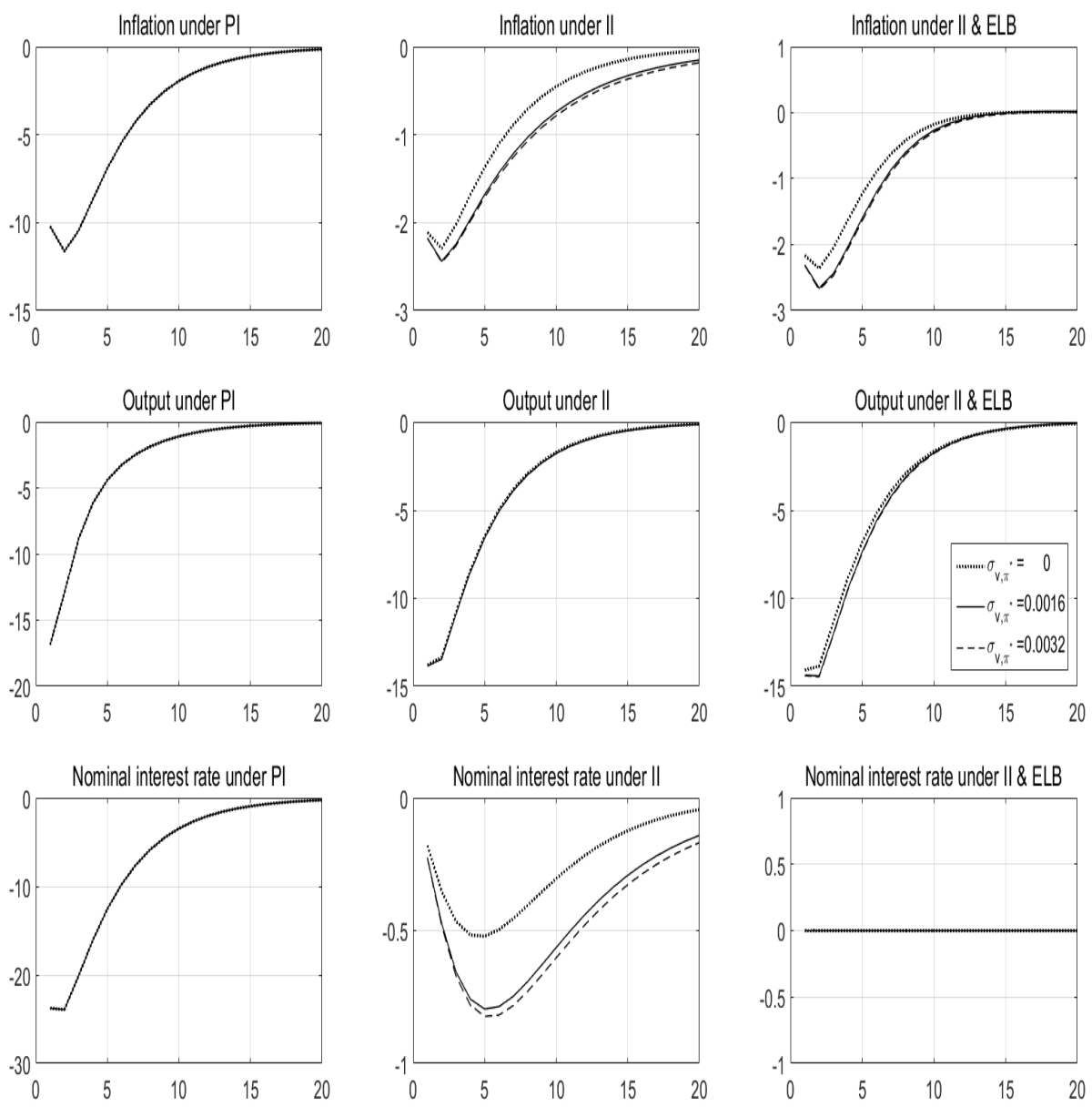

Notes: the charts in the left column show the responses under perfect information (PI). The charts in the middle column show the responses under imperfect information (II) and for different degrees of measurement precision of the inflation target. The charts in the right column show the responses under II and for different degrees of measurement precision of the inflation target when the interest rate is at its effective lower bound (ELB). 
Figure 5. Impulse responses to a negative inflation target shock
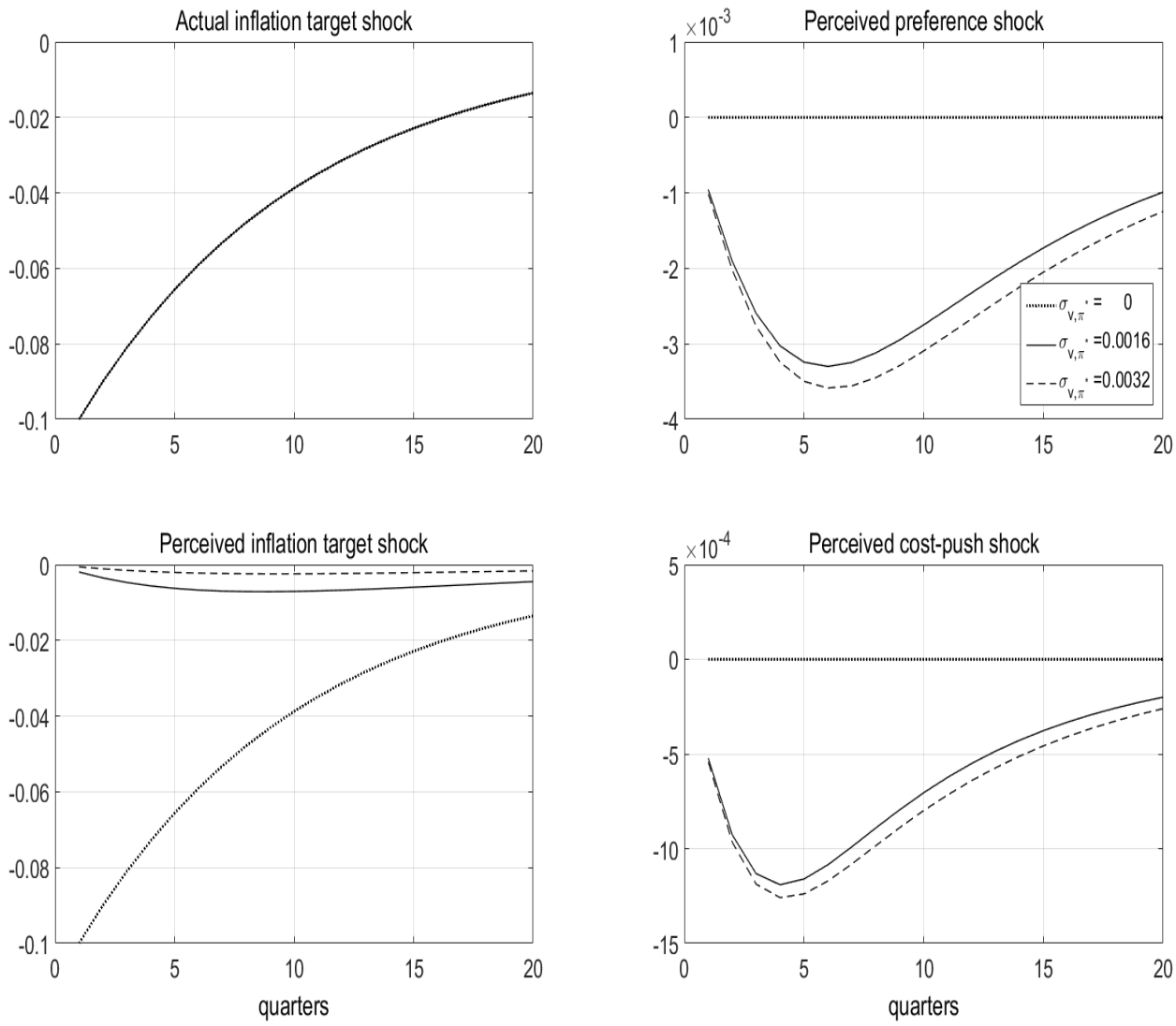

Notes: the figure shows the responses to a 0.1 shock to the inflation target for different degrees of measurement precision of the inflation target. 
Figure 6. Impulse responses to a negative inflation target shock (percentage deviations)
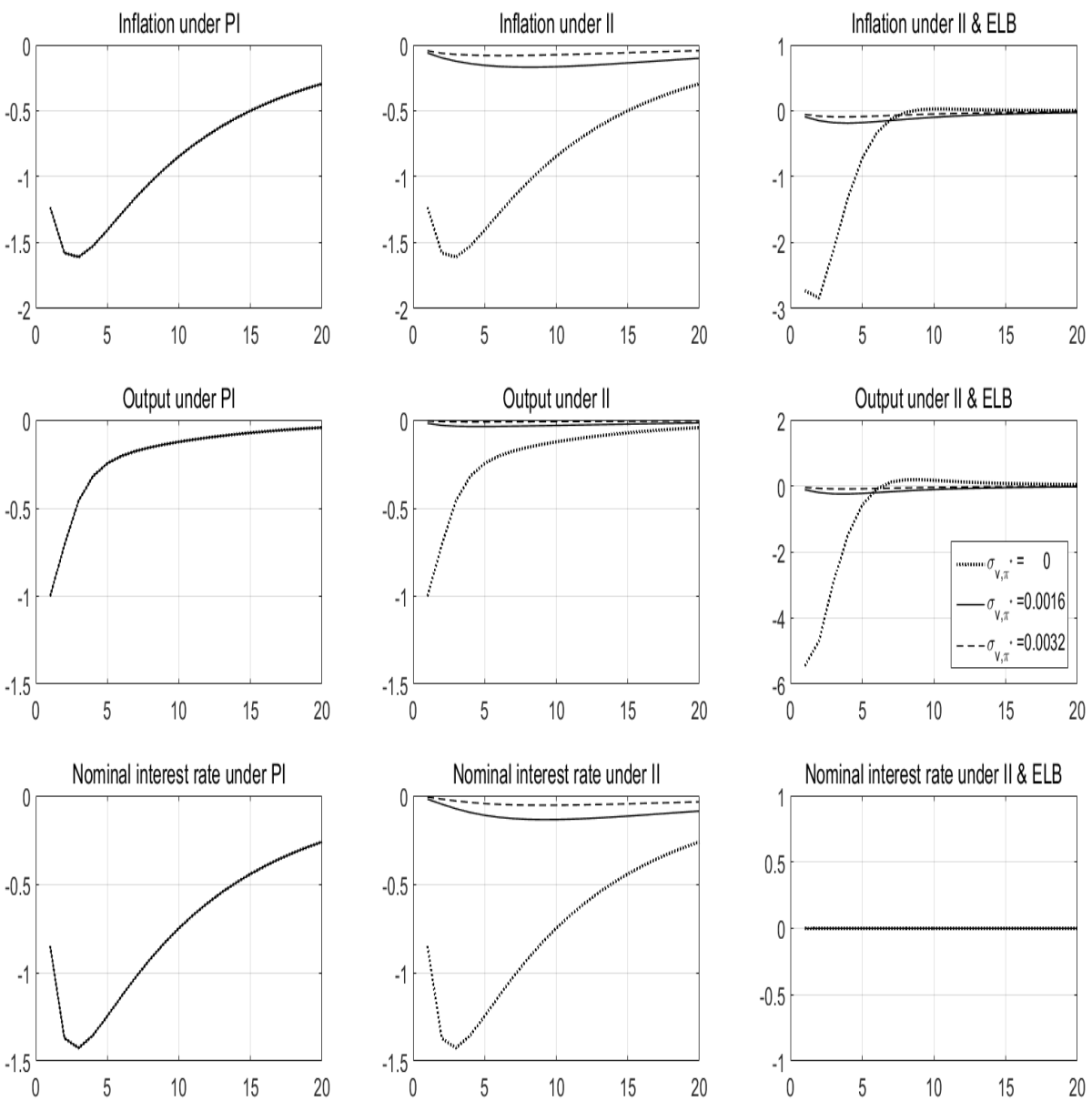

Notes: the charts in the left column show the responses under perfect information (PI). The charts in the middle column show the responses under imperfect information (II) and for different degrees of measurement precision of the inflation target. The charts in the right column show the responses under II and for different degrees of measurement precision of the inflation target when the interest rate is at its effective lower bound (ELB). 
Figure 7. Impulse responses to a favorable cost-push shock: larger degree of habit in consumption

(percentage deviations)
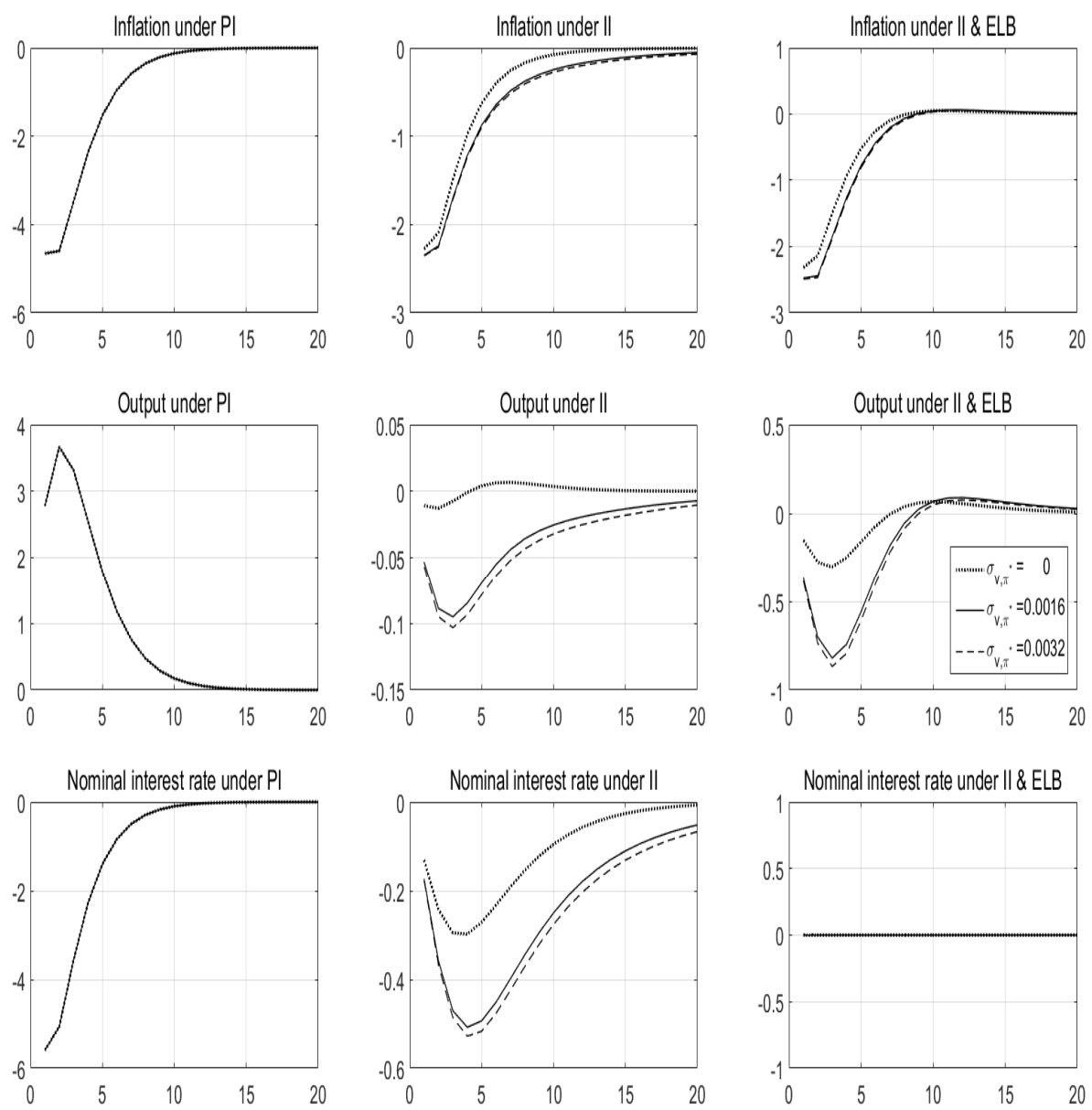

Notes: the parameter measuring the degree of habit in consumption, $\gamma$, is set to 0.5 , twice the value in Table 1 . The charts in the left column show the responses under perfect information (PI). The charts in the middle column show the responses under imperfect information (II) and for different degrees of measurement precision of the inflation target. The charts in the right column show the responses under II and for different degrees of measurement precision of the inflation target when the interest rate is at its effective lower bound (ELB). 
Figure 8. Impulse responses to a favorable cost-push shock: no habit in consumption

(percentage deviations)
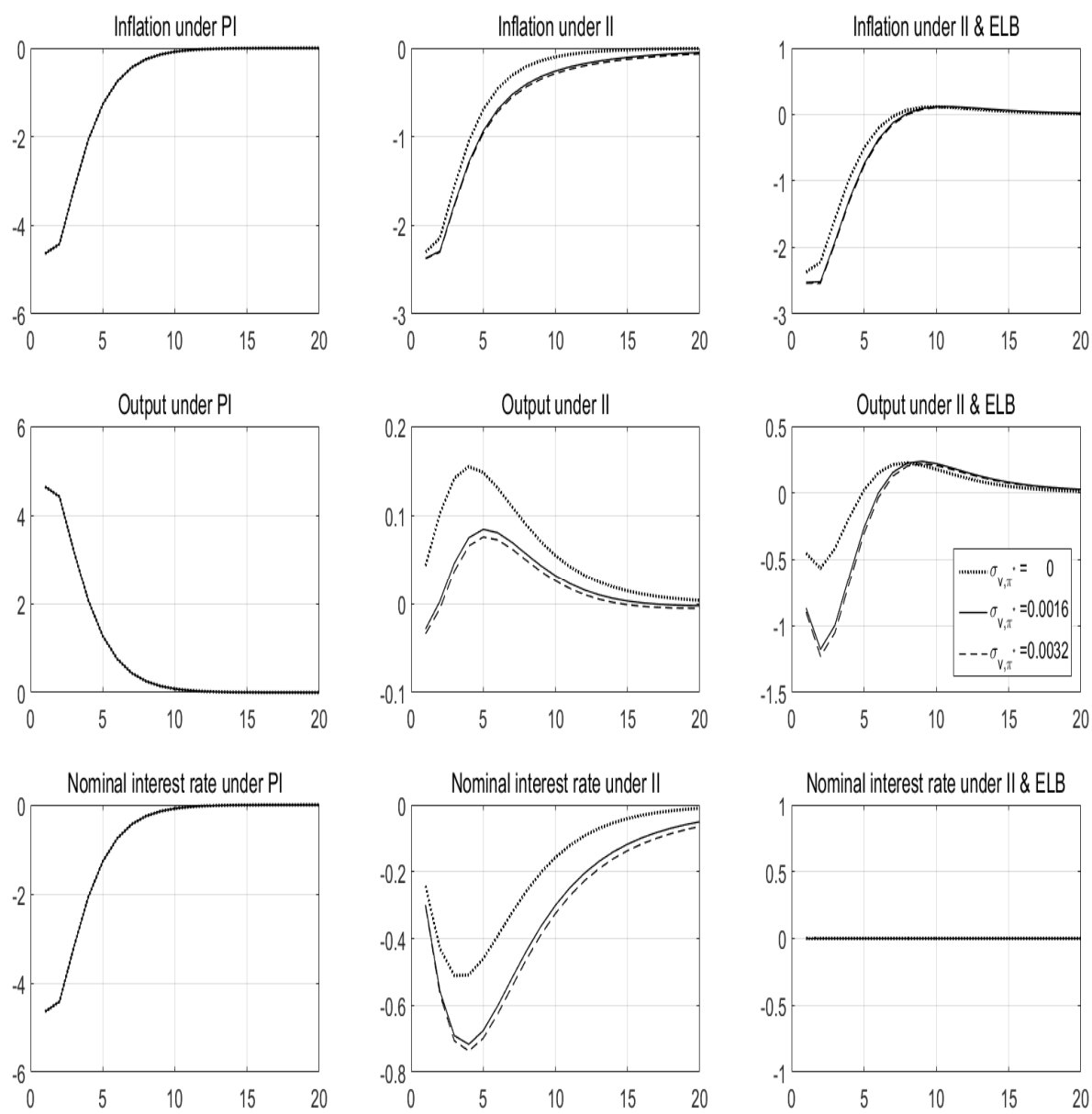

Notes: the parameter measuring the degree of habit in consumption, $\gamma$, is set to 0 . The charts in the left column show the responses under perfect information (PI). The charts in the middle column show the responses under imperfect information (II) and for different degrees of measurement precision of the inflation target. The charts in the right column show the responses under II and for different degrees of measurement precision of the inflation target when the interest rate is at its effective lower bound (ELB). 
Figure 9. Impulse responses to a favorable cost-push shock: no indexation of prices to past inflation

(percentage deviations)
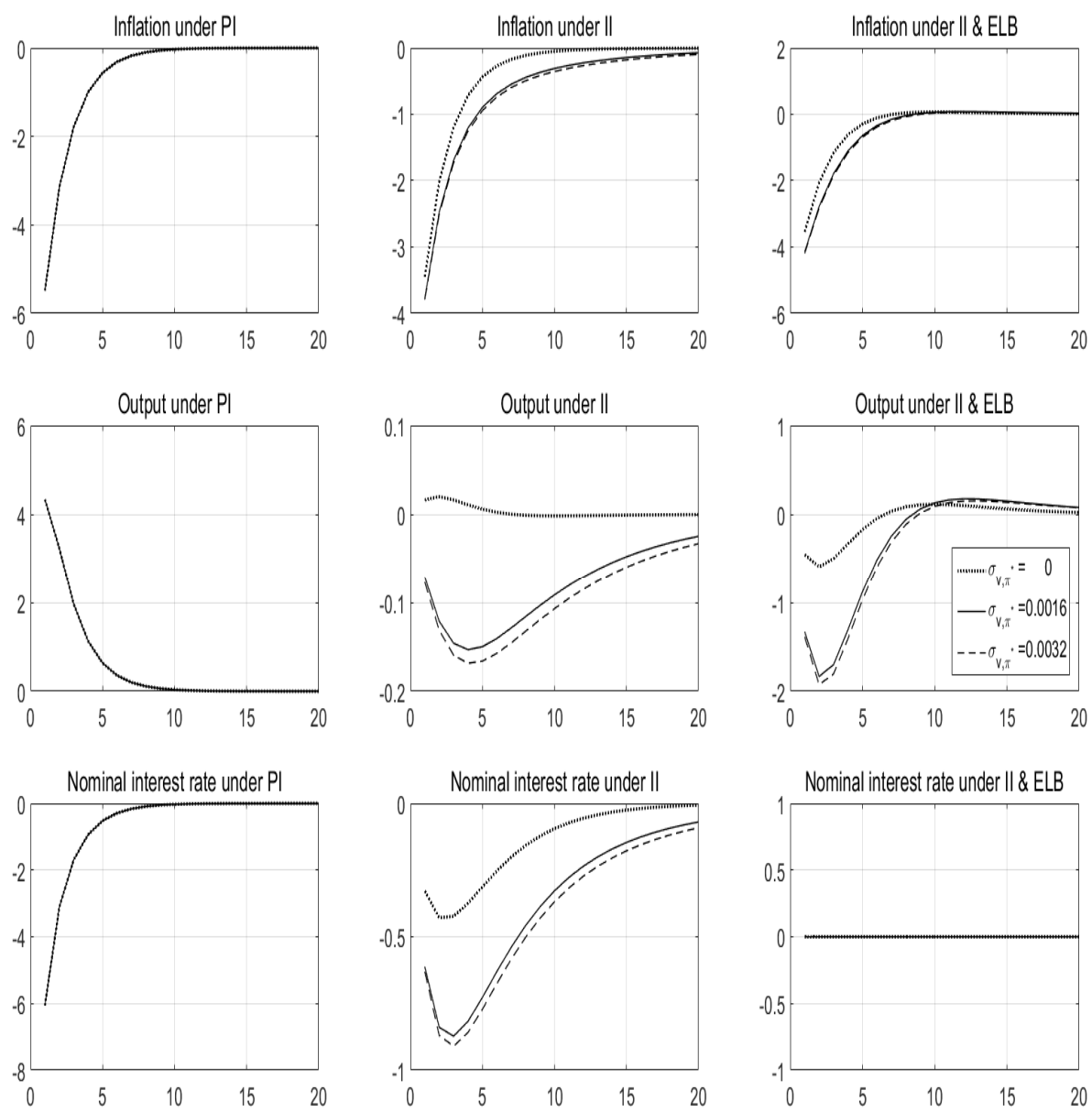

Notes: the parameter measuring the degree of indexation of prices to past inflation, $\alpha$, is set to 0 . The charts in the left column show the responses under perfect information (PI). The charts in the middle column show the responses under imperfect information (II) and for different degrees of measurement precision of the inflation target. The charts in the right column show the responses under II and for different degrees of measurement precision of the inflation target when the interest rate is at its effective lower bound (ELB). 


\section{References}

Ascari, G. and T. Ropele (2009). "Trend Inflation, Taylor Principle, and Indeterminacy”, Journal of Money, Credit and Banking, 41, 1557-1584.

Bernanke, B. S. and F. S. Mishkin (1997). "Inflation targeting: a new framework for monetary policy?", Journal of Economic Perspectives, 11, 97-116.

Blinder, A. (2007). "Monetary policy by committee: why and how?", European Journal of Political Economy, 23, 106-123.

Capistrán C. and M. Ramos-Francia (2007). "Does Inflation Targeting Affect the Dispersion of Inflation Expectations?", Journal of Money, Credit and Banking, 42, 113-134.

Clarida, R., J. Galí, and M. Gertler (1999). "The Science of Monetary Policy: A New Keynesian Perspective", Journal of Economic Literature, 37, 1661-1707.

Coenen, G., A. T. Levin and V. Wieland (2005). "Data uncertainty and the role of money as an information variable for monetary policy", European Economic Review 49, 975-1006.

Davis, J. S. (2014). "Inflation targeting and the anchoring of inflation expectations: crosscountry evidence from Consensus Forecasts", Federal Reserve Bank of Dallas Globalization and Monetary Policy Institute, Working Paper 174.

Erceg, C. J. and A. T. Levin (2003). "Imperfect credibility and inflation persistence", Journal of Monetary Economics 50, 915-944.

Galí, J. (2003). New perspectives on monetary policy, inflation, and the business cycle. In M. Dewatripont, L. Hansen, and S. Turnovsky (Eds.), Advances in Economic Theory, 151197. Cambridge University Press.

Gelos, G. and Y. Ustyugova (2017). "Inflation responses to commodity price shocks - How and why do countries differ?", Journal of International Money and Finance, 72, 28-47.

Gerali, A., S. Neri, L. Sessa and F. M. Signoretti (2010). "Credit and banking in a DSGE model of the euro area", Journal of Money, Credit and Banking 42(S2), 107-141.

Gerali, A. and F. Lippi (2003). "Optimal control and filtering in linear forward-looking economies: a toolkit", CEPR Discussion Paper 3706.

Ireland, P. N. (2007). “Changes in the Federal Reserve's inflation target: causes and consequences", Journal of Money, Credit and Banking 39, 1851-1882. 
Melecký, M., D. R. Palenzuela and U. Söderström (2009). "Inflation target transparency and the macroeconomy", in "Monetary policy under uncertainty and learning", K. SchmidtHebbel, C. E. Walsh and N. Loayza, eds., 371-411. Santiago, Chile: Central Bank of Chile.

Mishkin, F. S. and K. Schmidt-Hebbel (2007). “Does inflation targeting make a difference?", NBER Working Paper 12876.

Neri, S. and T. Ropele (2011). "Imperfect information, real-time data and monetary policy in the euro area", The Economic Journal 122, 651-674.

Rotemberg, J. J. (1982). "Monopolistic price adjustment and aggregate output”, The Review of Economic Studies 49, 517-531.

Svensson, L. E. O. and M. Woodford (2003). “Indicator variables for optimal policy”, Journal of Monetary Economics 50, 691-720.

Svensson, L. E. O. and M. Woodford (2004). "Indicator variables for optimal policy under asymmetric information", Journal of Economic Dynamics \& Control, 28, 661-690.

Taylor, J. B. (1993). "Discretion versus policy rules in practice”, Carnegie-Rochester Conference Series on Public Policy 39, 195-214.

Woodford, M. (2003). Interest and Prices: Foundations of a Theory of Monetary Policy. Princeton, NJ: Princeton University Press. 


\section{RECENTLY PUBLISHED “TEMI” (*)}

N. 1208 - The Economic Effects of Big Events: Evidence from the Great Jubilee 2000 in Rome, by Raffaello Bronzini, Sauro Mocetti and Matteo Mongardini (February 2019).

N. 1209 - The added value of more accurate predictions for school rankings, by Fritz Schiltz, Paolo Sestito, Tommaso Agasisti and Kristof De Witte (February 2019).

N.1210 - Identification and estimation of triangular models with a binary treatment, by Santiago Pereda Fernández (March 2019).

N.1211 - U.S. shale producers: a case of dynamic risk management, by Fabrizio Ferriani and Giovanni Veronese (March 2019).

N.1212 - Bank resolution and public backstop in an asymmetric banking union, by Anatoli Segura Velez (March 2019).

N.1213 - A regression discontinuity design for categorical ordered running variables with an application to central bank purchases of corporate bonds, by Fan Li, Andrea Mercatanti, Taneli Mäkinen and Andrea Silvestrini (March 2019).

N. 1214 - Anything new in town? The local effects of urban regeneration policies in Italy, by Giuseppe Albanese, Emanuele Ciani and Guido de Blasio (April 2019).

N. 1215 - Risk premium in the era of shale oil, by Fabrizio Ferriani, Filippo Natoli, Giovanni Veronese and Federica Zeni (April 2019).

N.1216 - Safety traps, liquidity and information-sensitive assets, by Michele Loberto (April 2019).

N. 1217 - Does trust among banks matter for bilateral trade? Evidence from shocks in the interbank market, by Silvia Del Prete and Stefano Federico (April 2019).

N.1218 - Monetary policy, firms' inflation expectations and prices: causal evidence from firm-level data, by Marco Bottone and Alfonso Rosolia (April 2019).

N.1219 - Inflation expectations and firms' decisions: new causal evidence, by Olivier Coibion, Yuriy Gorodnichenko and Tiziano Ropele (April 2019).

N. 1220 - Credit risk-taking and maturity mismatch: the role of the yield curve, by Giuseppe Ferrero, Andrea Nobili and Gabriele Sene (April 2019).

N. 1221 - Big-city life (dis)satisfaction? The effect of living in urban areas on subjective wellbeing, by David Loschiavo (June 2019).

N. 1222 - Urban agglomerations and firm access to credit, by Amanda Carmignani, Guido de Blasio, Cristina Demma and Alessio D'Ignazio (June 2019).

N. 1223 - The international transmission of US tax shocks: a proxy-SVAR approach, by Luca Metelli and Filippo Natoli (June 2019).

N. 1224 - Forecasting inflation in the euro area: countries matter!, by Angela Capolongo and Claudia Pacella (June 2019).

N. 1225 - Domestic and global determinants of inflation: evidence from expectile regression, by Fabio Busetti, Michele Caivano and Davide Delle Monache (June 2019).

N. 1226 - Relative price dynamics in the Euro area: where do we stand?, by Pietro Cova and Lisa Rodano (June 2019).

N.1227 - Optimally solving banks' legacy problems, by Anatoli Segura and Javier Suarez (June 2019).

(*) Requests for copies should be sent to:

Banca d'Italia - Structural Economic Analysis Directorate - Library Division - Via Nazionale, 91 - 00184 Rome - (fax 003906 47922059). They are available on the Internet www.bancaditalia.it. 
Aaberge, R., F. Bourguignon, A. Brandolini, F. Ferreira, J. Gornick, J. Hills, M. Jäntti, S. Jenkins, J. Micklewright, E. Marlier, B. Nolan, T. Piketty, W. Radermacher, T. Smeeding, N. Stern, J. Stiglitz, H. Sutherland, Tony Atkinson and his legacy, Review of Income and Wealth, v. 63, 3, pp. 411-444, WP 1138 (September 2017).

AcCetturo A., M. Bugamelli and A. LAmorgese, Law enforcement and political participation: Italy 1861-65, Journal of Economic Behavior \& Organization, v. 140, pp. 224-245, WP 1124 (July 2017).

AdAmopoulou A. and G.M. TANZI, Academic dropout and the great recession, Journal of Human Capital, V. 11, 1, pp. 35-71, WP 970 (October 2014).

Albertazzi U., M. BotTero and G. SENE, Information externalities in the credit market and the spell of credit rationing, Journal of Financial Intermediation, v. 30, pp. 61-70, WP 980 (November 2014).

AlESSANDRI P. and H. MUMTAZ, Financial indicators and density forecasts for US output and inflation, Review of Economic Dynamics, v. 24, pp. 66-78, WP 977 (November 2014).

BARbieri G., C. Rossetti and P. SESTITO, Teacher motivation and student learning, Politica economica/Journal of Economic Policy, v. 33, 1, pp.59-72, WP 761 (June 2010).

Bentivogli C. and M. LitTERIO, Foreign ownership and performance: evidence from a panel of Italian firms, International Journal of the Economics of Business, v. 24, 3, pp. 251-273, WP 1085 (October 2016).

BRONZINI R. and A. D'IGNAZIO, Bank internationalisation and firm exports: evidence from matched firmbank data, Review of International Economics, v. 25, 3, pp. 476-499 WP 1055 (March 2016).

BRUChE M. and A. SEgurA, Debt maturity and the liquidity of secondary debt markets, Journal of Financial Economics, v. 124, 3, pp. 599-613, WP 1049 (January 2016).

Burlon L., Public expenditure distribution, voting, and growth, Journal of Public Economic Theory,, v. 19, 4, pp. 789-810, WP 961 (April 2014).

Burlon L., A. Gerali, A. Notarpietro and M. PisAni, Macroeconomic effectiveness of non-standard monetary policy and early exit. a model-based evaluation, International Finance, v. 20, 2, pp.155173, WP 1074 (July 2016).

BusEtTi F., Quantile aggregation of density forecasts, Oxford Bulletin of Economics and Statistics, v. 79, 4, pp. 495-512, WP 979 (November 2014).

CESARONI T. and S. IEZZI, The predictive content of business survey indicators: evidence from SIGE, Journal of Business Cycle Research, v.13, 1, pp 75-104, WP 1031 (October 2015).

CONTI P., D. MARELLA and A. NERI, Statistical matching and uncertainty analysis in combining household income and expenditure data, Statistical Methods \& Applications, v. 26, 3, pp 485-505, WP 1018 (July 2015).

D’AMURI F., Monitoring and disincentives in containing paid sick leave, Labour Economics, v. 49, pp. 7483, WP 787 (January 2011).

D'AMURI F. and J. MARCUCCI, The predictive power of google searches in forecasting unemployment, International Journal of Forecasting, v. 33, 4, pp. 801-816, WP 891 (November 2012).

DE BLASIO G. and S. POY, The impact of local minimum wages on employment: evidence from Italy in the 1950s, Journal of Regional Science, v. 57, 1, pp. 48-74, WP 953 (March 2014).

Del Giovane P., A. NobiLi and F. M. Signoretti, Assessing the sources of credit supply tightening: was the sovereign debt crisis different from Lehman?, International Journal of Central Banking, v. 13, 2, pp. 197-234, WP 942 (November 2013).

Del Prete S., M. PAGNini, P. Rossi and V. VACCA, Lending organization and credit supply during the 2008-2009 crisis, Economic Notes, v. 46, 2, pp. 207-236, WP 1108 (April 2017).

Delle Monache D. and I. Petrella, Adaptive models and heavy tails with an application to inflation forecasting, International Journal of Forecasting, v. 33, 2, pp. 482-501, WP 1052 (March 2016).

FEDERICO S. and E. TOSTI, Exporters and importers of services: firm-level evidence on Italy, The World Economy, v. 40, 10, pp. 2078-2096, WP 877 (September 2012).

Giacomelli S. and C. MEnOn, Does weak contract enforcement affect firm size? Evidence from the neighbour's court, Journal of Economic Geography, v. 17, 6, pp. 1251-1282, WP 898 (January 2013).

Loberto M. and C. Perricone, Does trend inflation make a difference?, Economic Modelling, v. 61, pp. 351-375, WP 1033 (October 2015). 
MANCINI A.L., C. MonfARdini and S. PASQUA, Is a good example the best sermon? Children's imitation of parental reading, Review of Economics of the Household, v. 15, 3, pp 965-993, WP No. 958 (April 2014).

MEEKS R., B. NELSON and P. AlessANDRI, Shadow banks and macroeconomic instability, Journal of Money, Credit and Banking, v. 49, 7, pp. 1483-1516, WP 939 (November 2013).

MiCUCCI G. and P. Rossi, Debt restructuring and the role of banks' organizational structure and lending technologies, Journal of Financial Services Research, v. 51, 3, pp 339-361, WP 763 (June 2010).

Mocetti S., M. PAGNini and E. SETTE, Information technology and banking organization, Journal of Journal of Financial Services Research, v. 51, pp. 313-338, WP 752 (March 2010).

MocETti S. and E. VIVIANO, Looking behind mortgage delinquencies, Journal of Banking \& Finance, v. 75, pp. 53-63, WP 999 (January 2015).

Nobili A. and F. Zollino, A structural model for the housing and credit market in Italy, Journal of Housing Economics, v. 36, pp. 73-87, WP 887 (October 2012).

PALAZZO F., Search costs and the severity of adverse selection, Research in Economics, v. 71, 1, pp. 171197, WP 1073 (July 2016).

Patacchini E. and E. Rainone, Social ties and the demand for financial services, Journal of Financial Services Research, v. 52, 1-2, pp 35-88, WP 1115 (June 2017).

PATACCHINI E., E. RAINONE and Y. ZENOU, Heterogeneous peer effects in education, Journal of Economic Behavior \& Organization, v. 134, pp. 190-227, WP 1048 (January 2016).

Sbrana G., A. Silvestrini and F. VenditTI, Short-term inflation forecasting: the M.E.T.A. approach, International Journal of Forecasting, v. 33, 4, pp. 1065-1081, WP 1016 (June 2015).

SEgurA A. and J. SuAREZ, How excessive is banks' maturity transformation?, Review of Financial Studies, v. 30, 10, pp. 3538-3580, WP 1065 (April 2016).

VACCA V., An unexpected crisis? Looking at pricing effectiveness of heterogeneous banks, Economic Notes, v. 46, 2, pp. 171-206, WP 814 (July 2011).

VERGARA CAFFARELI F., One-way flow networks with decreasing returns to linking, Dynamic Games and Applications, v. 7, 2, pp. 323-345, WP 734 (November 2009).

ZAGHINI A., A Tale of fragmentation: corporate funding in the euro-area bond market, International Review of Financial Analysis, v. 49, pp. 59-68, WP 1104 (February 2017).

Accetturo A., v. Di Giacinto, G. Micucci and M. Pagnini, Geography, productivity and trade: does selection explain why some locations are more productive than others?, Journal of Regional Science, v. 58, 5, pp. 949-979, WP 910 (April 2013).

AdAmopoulou A. and E. KAYA, Young adults living with their parents and the influence of peers, Oxford Bulletin of Economics and Statistics,v. 80, pp. 689-713, WP 1038 (November 2015).

ANDini M., E. Ciani, G. DE Blasio, A. D'Ignazio and V. Silvestrini, Targeting with machine learning: an application to a tax rebate program in Italy, Journal of Economic Behavior \& Organization, v. 156, pp. 86-102, WP 1158 (December 2017).

BARONE G., G. DE BLASIO and S. MOCETTI, The real effects of credit crunch in the great recession: evidence from Italian provinces, Regional Science and Urban Economics, v. 70, pp. 352-59, WP 1057 (March 2016).

Belotti F. and G. IlARDI Consistent inference in fixed-effects stochastic frontier models, Journal of Econometrics, v. 202, 2, pp. 161-177, WP 1147 (October 2017).

Berton F., S. Mocetti, A. Presbitero and M. Richiardi, Banks, firms, and jobs, Review of Financial Studies, v.31, 6, pp. 2113-2156, WP 1097 (February 2017).

Bofondi M., L. CARPInElli and E. SETTE, Credit supply during a sovereign debt crisis, Journal of the European Economic Association, v.16, 3, pp. 696-729, WP 909 (April 2013).

BokAn N., A. Gerali, S. Gomes, P. JACQUINOT and M. PISANI, EAGLE-FLI: a macroeconomic model of banking and financial interdependence in the euro area, Economic Modelling, v. 69, C, pp. 249280, WP 1064 (April 2016). 
BRILli Y. and M. TONELlo, Does increasing compulsory education reduce or displace adolescent crime? New evidence from administrative and victimization data, CESifo Economic Studies, v. 64, 1, pp. 15-4, WP 1008 (April 2015).

BUONO I. and S. FORMAI The heterogeneous response of domestic sales and exports to bank credit shocks, Journal of International Economics, v. 113, pp. 55-73, WP 1066 (March 2018).

Burlon L., A. GERAli, A. NotARPIETRO and M. PisAnI, Non-standard monetary policy, asset prices and macroprudential policy in a monetary union, Journal of International Money and Finance, v. 88, pp. 25-53, WP 1089 (October 2016).

CARTA F. and M. DE PHLIPPIS, You've Come a long way, baby. Husbands' commuting time and family labour supply, Regional Science and Urban Economics, v. 69, pp. 25-37, WP 1003 (March 2015).

CARTA F. and L. RIzZICA, Early kindergarten, maternal labor supply and children's outcomes: evidence from Italy, Journal of Public Economics, v. 158, pp. 79-102, WP 1030 (October 2015).

Casiraghi M., E. Gaiotti, L. Rodano and A. Secchi, A "Reverse Robin Hood”? The distributional implications of non-standard monetary policy for Italian households, Journal of International Money and Finance, v. 85, pp. 215-235, WP 1077 (July 2016).

CECChetti S., F. NATOLI and L. SigAlotTI, Tail co-movement in inflation expectations as an indicator of anchoring, International Journal of Central Banking, v. 14, 1, pp. 35-71, WP 1025 (July 2015).

CIANI E. and C. DEIANA, No Free lunch, buddy: housing transfers and informal care later in life, Review of Economics of the Household, v.16, 4, pp. 971-1001, WP 1117 (June 2017).

Cipriani M., A. Guarino, G. Guazzarotti, F. TAgliati and S. Fisher, Informational contagion in the laboratory, Review of Finance, v. 22, 3, pp. 877-904, WP 1063 (April 2016).

de Blasio G, S. De Mitri, S. D’Ignazio, P. Finaldi Russo and L. Stoppani, Public guarantees to SME borrowing. A RDD evaluation, Journal of Banking \& Finance, v. 96, pp. 73-86, WP 1111 (April 2017).

Gerali A., A. LocARno, A. NotArPIETRO and M. PISANI, The sovereign crisis and Italy's potential output, Journal of Policy Modeling, v. 40, 2, pp. 418-433, WP 1010 (June 2015).

LIBERATI D., An estimated DSGE model with search and matching frictions in the credit market, International Journal of Monetary Economics and Finance (IJMEF), v. 11, 6, pp. 567-617, WP 986 (November 2014).

LinAREllo A., Direct and indirect effects of trade liberalization: evidence from Chile, Journal of Development Economics, v. 134, pp. 160-175, WP 994 (December 2014).

NUCCI F. and M. RigGI, Labor force participation, wage rigidities, and inflation, Journal of Macroeconomics, v. 55, 3 pp. 274-292, WP 1054 (March 2016).

RIGON M. and F. ZANETTI, Optimal monetary policy and fiscal policy interaction in a non ricardian economy, International Journal of Central Banking, v. 14 3, pp. 389-436, WP 1155 (December 2017).

SEGURA A., Why did sponsor banks rescue their SIVs?, Review of Finance, v. 22, 2, pp. 661-697, WP 1100 (February 2017).

ARnAudo D., G. MiCUCCI, M. RIGON and P. Rossi, Should I stay or should I go? Firms' mobility across banks in the aftermath of the financial crisis, Italian Economic Journal / Rivista italiana degli economisti, v. 5, 1, pp. 17-37, WP 1086 (October 2016).

Cappelletti G., G. Guazzarotti and P. Tommasino, Tax deferral and mutual fund inflows: evidence from a quasi-natural experiment, Fiscal Studies, v. 40, 2, pp. 211-237, WP 938 (November 2013).

CIANI E., F. DAVID and G. DE BLASIO, Local responses to labor demand shocks: a re-assessment of the case of Italy, Regional Science and Urban Economics, v. 75, pp. 1-21, WP 1112 (April 2017).

CIANI E. and P. FISHER, Dif-in-dif estimators of multiplicative treatment effects, Journal of Econometric Methods, v. 8. 1, pp. 1-10, WP 985 (November 2014).

Chiades P., L. Greco, V. Mengotto, L. Moretti and P. Valbonesi, Fiscal consolidation by intergovernmental transfers cuts? The unpleasant effect on expenditure arrears, Economic Modelling, v. 77, pp. 266-275, WP 985 (July 2016). 
Coletta M., R. De Bonis and S. Piermattei, Household debt in OECD countries: the role of supply-side and demand-side factors, Social Indicators Research, v. 143, 3, pp. 1185-1217, WP 989 (November 2014).

COVA P., P. PAGANO and M. PISANI, Domestic and international macroeconomic effects of the Eurosystem Expanded Asset Purchase Programme, IMF Economic Review, v. 67, 2, pp. 315-348, WP 1036 (October 2015).

Giordano C., M. MARINUCCI and A. SiLvestrini, The macro determinants of firms' and households' investment: evidence from Italy, Economic Modelling, v. 78, pp. 118-133, WP 1167 (March 2018).

MONTEFORTE L. and V. RAPONI, Short-term forecasts of economic activity: are fortnightly factors useful?, Journal of Forecasting, v. 38, 3, pp. 207-221, WP 1177 (June 2018).

MercatANTI A., T. MAKINEN and A. SiLVESTRINI, The role of financial factors for european corporate investment, Journal of International Money and Finance, v. 96, pp. 246-258, WP 1148 (October 2017).

NERI S. and A. NOTARPIETRO, Collateral constraints, the zero lower bound, and the debt-deflation mechanism, Economics Letters, v. 174, pp. 144-148, WP 1040 (November 2015).

RigGi M., Capital destruction, jobless recoveries, and the discipline device role of unemployment, Macroeconomic Dynamics, v. 23, 2, pp. 590-624, WP 871 (July 2012).

\section{FORTHCOMING}

AlbANese G., M. CiOfFI and P. TOMmAsino, Legislators' behaviour and electoral rules: evidence from an Italian reform, European Journal of Political Economy, WP 1135 (September 2017).

Albanese G., G. DE Blasio and P. Sestito, Trust, risk and time preferences: evidence from survey data, International Review of Economics, WP 911 (April 2013).

APRIGLIANO V., G. ARDIZZI and L. MONTEFORTE, Using the payment system data to forecast the economic activity, International Journal of Central Banking, WP 1098 (February 2017).

ARDUINI T., E. PATACCHINI and E. RAINONE, Treatment effects with heterogeneous externalities, Journal of Business \& Economic Statistics, WP 974 (October 2014).

BELOTTI F. and G. ILARDI, Consistent inference in fixed-effects stochastic frontier models, Journal of Econometrics, WP 1147 (October 2017).

BusetTi F. and M. CAIVANO, Low frequency drivers of the real interest rate: empirical evidence for advanced economies, International Finance, WP 1132 (September 2017).

CIANI E. and G. DE BLASIO, European structural funds during the crisis: evidence from Southern Italy, IZA Journal of Labor Policy, WP 1029 (October 2015).

CORSELlO F. and V. NISPI LANDI, Labor market and financial shocks: a time-varying analysis, Journal of Money, Credit and Banking, WP 1179 (June 2018).

Cova P., P. PAgano, A. Notarpietro and M. PISANI, Secular stagnation, R\&D, public investment and monetary policy: a global-model perspective, Macroeconomic Dynamics, WP 1156 (December 2017).

D'AMURI F., Monitoring and disincentives in containing paid sick leave, Labour Economics, WP 787 (January 2011).

D'IgnAZIO A. and C. MENON, The causal effect of credit Guarantees for SMEs: evidence from Italy, Scandinavian Journal of Economics, WP 900 (February 2013).

ERCOLANI V. and J. VALLE E AZEVEDO, How can the government spending multiplier be small at the zero lower bound?, Macroeconomic Dynamics, WP 1174 (April 2018).

FEDERICO S. and E. TOSTI, Exporters and importers of services: firm-level evidence on Italy, The World Economy, WP 877 (September 2012).

FERrERo G., M. GROSS and S. NERI, On secular stagnation and low interest rates: demography matters, International Finance, WP 1137 (September 2017).

GERALi A. and S. NeRI, Natural rates across the Atlantic, Journal of Macroeconomics, WP 1140 (September 2017).

Giacomelli S. and C. MENOn, Does weak contract enforcement affect firm size? Evidence from the neighbour's court, Journal of Economic Geography, WP 898 (January 2013). 
LIBERATI D. and M. LOBERTO, Taxation and housing markets with search frictions, Journal of Housing Economics, WP 1105 (March 2017).

Natoli F. and L. SigalotTi, Tail co-movement in inflation expectations as an indicator of anchoring, International Journal of Central Banking, WP 1025 (July 2015).

RAINONE E., The network nature of otc interest rates, Journal of Financial Markets, WP 1022 (July 2015).

RIZZICA L., Raising aspirations and higher education. evidence from the UK's widening participation policy, Journal of Labor Economics, WP 1188 (September 2018).

SEGURA A., Why did sponsor banks rescue their SIVs?, Review of Finance, WP 1100 (February 2017). 